\title{
PARAOXONASE AND ARYLESTERASE ACTIVITIES IN PREGNANT WOMEN WITH INTAUTERINE GROWTH RESTRICTION: A PRELIMINARY STUDY
}

\author{
Yelda OZKAN ${ }^{1}$, Ebru OZTURK ${ }^{1}$, Ozcan BALAT ${ }^{1}$, Mete Gurol UGUR ${ }^{1}$, Ozcan EREL ${ }^{2}$ \\ ${ }^{1}$ Department of Gynecology and Obstetric, Gaziantep University, Faculty of Medicine, Gaziantep, Turkey \\ 2 Ataturk Training and Reseach Hospital, Ankara, Turkey
}

\begin{abstract}
SUMMARY
Objective: To evaluate the role of paraoxonase and arylesterase activities in etiopathogenesis of intrauterine growth restriction Design: Prospective study

Setting: Gaziantep Üniversity, Medical School, Department of Obstetrics and Gynecology

Patients: Pregnant patient with intrauterine growth restriction.

Interventions: Serum analysis and rutin pregnancy interventions.

Main outcome measures: Serum paraoxonase and arylesterase activities.

Results: We have demonstrated higher paraoxonase and arylesterase activities in patient group.

Conclusions: This is the first report about the role of paraoxonase 1, which is a HDL-associated antioxidant enzyme, in etiopathogenesis of intrauterine growth restriction in English literature. Further studies to evaluate the importance of serum paraoxonase and arylesterase activities for prediction of intrauterine growth restriction are needed.
\end{abstract}

Key words: arylesterase, intrauterine growth restriction, paraoxonase

Journal of Turkish Society of Obstetrics and Gynecology, (J Turk Soc Obstet Gynecol), 2012; Vol: 9 Issue: 1 Pages: $32-6$

\section{İNTRAUTERIN GELIŞME KISITLILIĞI İZLENEN GEBELERDE PAROKSANAZ-ARILESTERAZ ENZIM AKTIVITELERİ: PILOT ÇALIŞMA}

\section{ÖZET}

Objectif: İntrauterin Gelişme Klsitlllı̆̆ etiyopatogenezinde paroksanaz ve arilesteraz enzim aktivitelerinin yerinin ortaya konulması Planlama: Prospektif

Ortam: Gaziantep Üniversitesi, Tıp Fakültesi, Kadın Hastalıkları ve Doğum AD

Hastalar: Intrauterin Gelişme Klsıtlılığı izlenen gebeler

Girişim: Serum analizi, hasta ve kontrol gruplarının rutin gebelik takibi

Değerlendirme parametreleri: Serum paroksanaz ve arilesteraz enzim aktiviteleri

Sonuç: Paroksanaz ve arilesteraz enzim aktiviteleri hasta grubunda anlamlı ölçüde yüksek olarak saptanmıştır Yorum: Bu çalışma HDL'ye bağlı antioksidan bir enzim olan paroksanaz 1 'in intrauterin gelişme kusitlllı̆̆ patofizyolojisinde yeri olduğunu ortaya koyan literatürdeki ilk çalışmadır. Bu konuda özellikle intrauterin gelişme kısıtlllı̆ı öngörüsünde paroksanaz ve arilesteraz enzim aktivitelerinin yerini ortaya koyan prospektif çalışmalara ihtiyaç vardır.

Anahtar kelimeler: arilesteraz, intrauterin gelişme klsıtlılığı, paroksanaz

Türk Jinekoloji ve Obstetrik Derneği Dergisi, (J Turk Soc Obstet Gynecol), 2012; Cilt: 9 Sayl: 1 Sayfa: 32- 6

Address for Correspondence: Yelda Özkan. Gaziantep Üniversitesi Kadın Hastalıkları ve Doğum Anabilim Dalı, Gaziantep Phone: + 90 (537) 2802316

e-mail: yeldaibar@hotmail.com

Received: 02 September 2011, revised: 29 October 2011, accepted: 31 October 2011, online publication: 08 . December 2011 


\section{INTRODUCTION}

Normal fetal growth is related to maternal, fetal, placental and external factors along with genetic growth potential. Impairment of one or more of these factors affects the fetal growth ${ }^{(1)}$. The American College of Obstetricians and Gynecologists (ACOG) defined intrauterine growth restriction (IUGR) as the estimated fetal weight below $10^{\text {th }}$ percentile for the gestational age ${ }^{(2)}$. IUGR is considered as an important reason of the perinatal mortality and morbidity in the modern obstetrics practice. Although the literature contains hundreds of studies that revealed the risk factors for IUGR, etiopathogenesis of IUGR, which occasionally occurs without any risk factors, could not been fully demonstrated. It is thought that, in the physiopathology of IUGR, placental failure, which is observed related to oxidative stress, played a key role ${ }^{(3)}$.

Paroxanase-1 (PON1) is an antioxidant enzyme bound to high-density lipoproteins with paroxanase (PON) and arylestherase (ARE) activities ${ }^{(4)}$. The studies that have been performed since its discovery in 1961 revealed that PON1 enzyme was involved in the physiopathology of the atherosclerosis and cardiovascular diseases, related to endothelial damage and vascular dysfunction $(5,6)$.

In this study, we aimed to evaluate PON and ARE activities of PON1 enzyme in IUGR, for which endothelial damage and vascular dysfunction were thought to play a role in the etiopathogenesis. This study has been the first study published in the literature, which evaluated PON and ARE activities in IUGR.

\section{MATERIAL AND METHODS}

This study was approved by Ethical Committee of the Gaziantep University, Medical Faculty (05/11/2009 D decree no. 11) and thereafter, was conducted with the grant with the project number of TF.10.18 given by Gaziantep University, Research Projects Found. We enrolled 50 patients who were hospitalized and followed up with the diagnosis of IUGR in the Clinic of Gynecology and Obstetrics Department of Gaziantep University Medical Faculty and 51 healthy pregnant women who were presented to the polyclinic at their third trimester between November 2009 and July 2010. For all pregnant women, demographic data, ultrasonographic data and Doppler parameters were recorded and they were prospectively monitorized. Exclusion criteria included fetal abnormality, chromosomal anomaly, fetal infection, multiple pregnancy, early membrane rupture, preeclampsia, eclampsia, maternal chronic disease (hypertension, endocrine diseases, connective tissue diseases, thrombophilies, hyperlipidemia, acute or chronic hepatic diseases), the use of the drugs that may affect the serum levels of the enzyme or smoking, the cases of inadequately measured Doppler parameters and the patients diagnosed with IUGR with a birth weight above $10^{\text {th }}$ percentile. Gestational week of the patients enrolled to the study was calculated using the date of the last menstruation and was confirmed by sonographic measurements done in the early pregnancy. The patients whose gestational week could not be exactly determined were not included to the study. In all subjects, fetal weight (EFW) was calculated using ultrasonographically obtained biparietal diameter, head circumference, femoral length and abdominal circumference. Pregnant women of each group were followed-up until the time of delivery and the diagnosis of IUGR were confirmed by a birth weight below 10th percentile.

All the ultrasonographic examinations and measurements were done using $4 \mathrm{MHz}$ convex probe with Toshiba Xario XG Color Doppler ultrasound device. Umbilical artery and middle cerebral artery were examined using Doppler ultrasonography. Arterial system was considered to be impaired if the loss of diastolic flow or reversed flow were observed in the umbilical artery, a systole to diastole ratio (S/D) was above $95^{\text {th }}$ percentile and middle cerebral arterial pulsatility index (PI) was below 5 th percentile. Patient group was subdivided into two subgroups as those with impaired arterial system (Group 1A) and normal patients (Group 1B).

Blood samples, which were obtained from antecubital veins of the subjects in the patient and control groups, were centrifuged at $3500 \mathrm{rpm}$ for 10 minutes and the serum samples separated were stored at $-20^{\circ} \mathrm{C}$ until the day of analysis. PON and ARE activities were evaluated using commercially available full-automatic kits (Relassay/Gaziantep/Turkey) ${ }^{(7)}$. The results obtained in the study were evaluated using SPSS (Statistical Package for Social Sciences) for Windows 15 software at $\% 95$ confidence interval and at a significance level of $\mathrm{p}<0.05$. 


\section{RESULTS}

In this study, no statistically significant difference was observed in terms of age, parity, gestational week at the time of blood sampling and body mass index between the patient group consisted of 50 pregnant women diagnosed with IUGR and control group consisted of 51 healthy pregnant women (Table I).

Table I: Demographic and clinical findings of the patient and control groups.

\begin{tabular}{llll}
\hline & $\begin{array}{l}\text { Patient group } \\
(\mathbf{n = 5 0}) \\
\text { Mean } \pm \text { SS }\end{array}$ & $\begin{array}{l}\text { Control group } \\
(\mathbf{n = 5 1 )} \\
\text { Mean } \pm \text { SS }\end{array}$ & p \\
\hline Age & $\begin{array}{l}28,7 \pm 5.8 \\
1,86 \pm 1,07\end{array}$ & $\begin{array}{l}28,5 \pm 5,6 \\
2,16 \pm 1,36\end{array}$ & $\begin{array}{l}\text { NS } \\
\text { Parity }\end{array}$ \\
$\begin{array}{llll}\text { Pregnancy week at the } \\
\text { time of blood sampling } 33,7 \pm 4,2\end{array}$ & $34,1 \pm 3,6$ & NS \\
Pregnancy week & $34,4 \pm 3,9$ & $39,1 \pm 1,1$ & $<0.05$ \\
At the delivery & $29,5 \pm 2,3$ & $29,9 \pm 2,8$ & NS \\
Body mass index & $3550 \pm 284$ & $<0.05$ \\
Birth weight of the baby $1668 \pm 665$ & $9,8 \pm 2,7 \pm$ & $<0.05$ \\
Amniotic fluid index & $3,9 \pm 1,2$ &
\end{tabular}

NS, not significant; SS, standard deviation

A statistically significant difference was observed between patient and control groups in terms of serum PON and ARE enzyme activities, leading to a significantly higher activity for both enzymes in the patient group with IUGR (Table II) (Figure 1).

Table II: paroxanase and arylesterase enzyme activities for patient and control groups.

\begin{tabular}{llll}
\hline & $\begin{array}{l}\text { Patient group } \\
(\mathbf{n}=\mathbf{5 0}) \text { Mean } \pm \text { SS }\end{array}$ & $\begin{array}{l}\text { Control group } \\
(\mathbf{n}=\mathbf{5 1}) \text { Mean } \pm \text { SS }\end{array}$ & p \\
\hline $\begin{array}{l}\text { Paroxanase enzyme } \\
\text { activity (U/L) }\end{array}$ & $174,0 \pm 105,5$ & $134,6 \pm 126,0$ & $<0.05$ \\
$\begin{array}{l}\text { Arylesterase enzyme } \\
\text { activity (U/L) }\end{array}$ & $242,1 \pm 125,4$ & $164,8 \pm 105,2$ & $<0.05$ \\
\hline
\end{tabular}

SS, standard deviation

Table III: Paroxanase and arylesterase activities of the pregnant women with impaired arterial system in the patient group (Group $1 A$ ) and of the normal pregnant women (Group IB).

\begin{tabular}{|c|c|c|c|}
\hline & $\begin{array}{l}\text { Group IA } \\
(n=34) \text { Mean } \pm \text { SS }\end{array}$ & $\begin{array}{l}\text { Group IB } \\
(n=16) \text { Mean } \pm \text { SS }\end{array}$ & p \\
\hline \multicolumn{4}{|c|}{ Paroxanase enzyme } \\
\hline activity (U/L) & $174,0 \pm 104,1$ & $168,6 \pm 105,4$ & NS \\
\hline \multicolumn{4}{|c|}{ Arylesterase enzyme } \\
\hline activity (U/L) & $240,2 \pm 124,3$ & $249,6,8 \pm 118,1$ & NS \\
\hline
\end{tabular}

NS, not significant; $S S$, standard deviation
Figure 1: Paroxanase (PON) and arylesterase (ARE) enzyme activities of the patient and control groups.

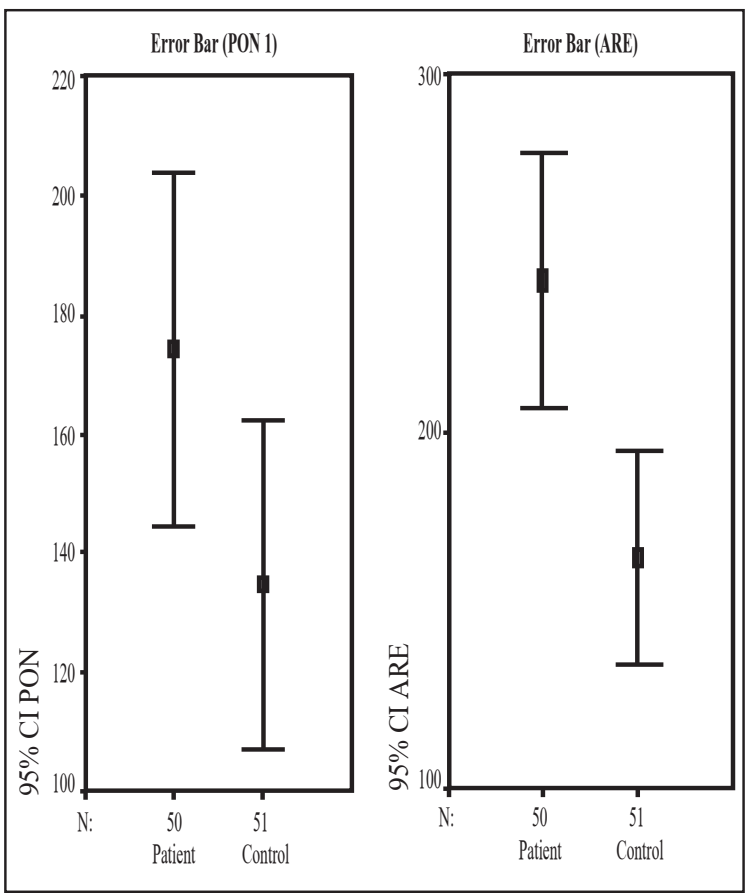

Control group did not exhibit arterial system impairment. In the patients group, 34 pregnant women showed arterial system impairment (Group 1a), whereas 16 pregnant women showed natural Doppler flows of umbilical artery and middle cerebral artery (Grup 1B). No statistically significant difference of serum PON and ARE enzyme activities was detected between the subgroups in which an impairment of arterial system was observed and was not observed among the pregnant women that showed IUGR (Table III).

\section{DISCUSSION}

Recent studies suggested that the complications of pregnancy, such as unexplained IUGR and early-onset preeclampsia, resulted from a common physiopathology (8-10). Accordingly, maternal spiral arteries observed during the first trimester of the pregnancy and anomalies of trophoblast invasion cause oxidative stress and, thereby, endothelial dysfunction resulting from oxidative stress plays a key role in the occurrence of pregnancy complications, such as $\operatorname{IUGR}^{(11)}$. For this issue, many studies were conducted to reveal the correlation between the parameters of oxidative stress and fetal weight(12-15).

PON1 enzyme, that has been firstly detected in the 
HDL immunoprecipitates in 1961, is a glycosylated protein with a molecule weight of approximately 43 $\mathrm{kDa}(16,17)$. Although the physiological role of PON1 is not fully known, it was demonstrated to prevent LDL oxidation by hydrolyzing lipid peroxides and to have a protective role against cellular damage that might be caused by toxic agents such as organophosphates $(18,19)$. PON1 is an enzyme that plays an important role in the antioxidant system of the liver microsomes ${ }^{(20)}$. It was demonstrated that PON1 enzyme activities were lower in the cases of atherosclerosis and cardiovascular disease resulting from endothelial damage $(5,6)$.

In the literature, the results of limited number of studies that evacuate PON and ARE activities in the pregnant women with preeclampsia with a physiopathology that involved endothelial dysfunction were conflicting(2124). In this subject, while Yaghmaei et al. detected high PON and ARE activities in the preeclamptic pregnant women ${ }^{(21)}$, Kumru et al. and Uzun et al. considered this activities as lower ${ }^{(22,23)}$.

Baker et al.(24) determined PON and ARE activities of PON1 enzyme at $15^{\text {th }}$ and $20^{\text {th }}$ gestational weeks and demonstrated that these two enzymatic activities were statistically higher in the group that developed preeclampsia among all pregnant women that they followed-up. Moreover, the patients were examined in two groups, as mild and severe preeclampsia, and the levels of enzyme were found to be higher in the group of severe disease compared to the group of mild disease.

Although the literature contained some studies that investigated PON and ARE activities in the preeclamptic pregnant women, our study has been the first study that evaluated the activities of PON and ARE enzymes in IUGR, which has been thought to share a common physiopathology with preeclampsia.

In our study, PON and ARE activities were found to be statistically significantly higher in IUGR group and this result was considered as a compensatory response rather than a reason. It was thought that the evaluation of this response especially during the first trimester could play a role in the prediction of IUGR. The fact that there was no difference of PON and ARE activities between the groups that showed and did not show an impaired arterial system in the patient group was interpreted as the lack of a correlation between these enzymatic activities and prognosis.

Consequently, this study has been the first study that highlighted the important place of PON1, a HDLrelated antioxidant enzyme, in the physiopathology of IUGR. Further prospective studies are needed to evidence the place of PON and ARE activities in this subject and especially in the prediction of IUGR.

\section{REFERENCES}

1. Bernstein PS, Divon MY. Etiologies of fetal growth restriction. Clin Obstet Gynecol 1997; 40: 723- 9.

2. American College of Obstetricians and Gynecologists: Clinical Management Guidelines for Obstetricians - Gynecologists. ACOG Practise Bulletin No. 12 American College of Obstetricians and Gynecologists, 2000.

3. Sankaran S, Kyle PM. Aetiology and pathogenesis of IUGR. Best Pract Res Clin Obstet Gynaecol 2009; 23: 765- 77.

4. Canales A, Sanchez-Muniz FJ. Paraoxonase, something more than an enzyme? Med Clin 2003; 121: 537- 48.

5. Mackness B, Durrington PN, Mackness MI. Human serum paraoxonase. Gen Pharmacol 1998; 31: 329- 36.

6. Soran H, Younis NN, Charlton-Menys V, et al. Variation in paraoxonase-1 activity and atherosclerosis. Curr Opin Lipidol 2009; 20: 265- 74

7. Ozturk E, Balat O, Dikensoy E, et al. No association between serum paraoxonase, arylesterase activities, and hydatidiform mole. Int J Gynecol Cancer 2011; 21: 149- 52

8. Myatt L, Cui X. Oxidative stress in the placenta. Histochem Cell Biol 2004; 122: 369- 82.

9. Burton GJ, Yung HW, Cindrova-Davies T, Charnock-Jones DS. Placental endoplasmic reticulum stress and oxidative stress in the pathophysiology of unexplained intrauterine growth restriction and early onset preeclampsia. Placenta $2009 ; 30 ; 43-8$.

10. Gupta S, Agarwal A, Sharma RK. The role of placental oxidative stress and lipid peroxidation in preeclampsia. Obstet Gynecol Surv 2005; 60: 807- 16.

11. Henriksen $\mathrm{T}$. The role of lipid oxidation and oxidative lipid derivatives in the development of preeclampsia. Semin Perinatol 2000; 24: 29- 32.

12. Min J, Park B, Kim YJ, Lee H, Ha E, Park H. Effect of oxidative stress on birth sizes: consideration of window from mid pregnancy to delivery. Placenta 2009; 30: 418- 23.

13. Potdar N, Singh R, Mistry V, et al. First-trimester increase in oxidative stress and risk of small-for-gestational-age fetus. BJOG 2009; 116: 637- 42

14. Gveric-Ahmetasevic S, Sunjic SB, Skala H, et al. Oxidative stress in small-for-gestational age (SGA) term newborns and 
their mothers. Free Radic Res 2009; 43: 376- 84.

15. Kim YJ, Hong YC, Lee KH, et al. Oxidative stress in pregnant women and birth weight reduction. Reprod Toxicol 2005; 19: 487- 92 .

16. Eckerson HW, Romson J, Wyte C, La Du BN. The human serumparaoxonase polymorphism: identification of phenotypes by their response to salts. Am J Hum Genet 1983; 35: 21427.

17. Gan KN, Smolen A, Eckerson HW, La Du BN. Purification of human serum paraoxonase/arylesterase. Evidence for one esterase catalyzing both activities. Drug Metab Dispos 1991; 19: $100-6$.

18. Primo-Parmo SL, Sorenson RC, Teiber J, La Du BN. The human serum paraoxonase/arylesterase gene (PON1) is one member of a multigene family. Genomics 1996; 33: 498- 507

19. La Du BN, Aviram M, Billecke S, et al. On the physiological role(s) of the paraoxonases. Chem Biol Interact 1999; 119120: $379-88$.
20. Ferre N, Camps J, Cabre M, Paul A, Joven J. Hepatic paraoxonase activity alterations and free radical production in rats with experimental cirrhosis. Metabolism 2001; 50: 997- 1000.

21. Yaghmaei M, Hashemi M, Azarian A, et al. Association of L55M and Q192R Polymorphisms of Paraoxonase-1 Gene with Preeclampsia. Arch Med Res 2011; 42: 324- 8.

22. Uzun H, Benian A, Madazli R, Topçuoğlu MA, Aydin S, Albayrak M. Circulating oxidized low-density lipoprotein and paraoxonase activity in preeclampsia. Gynecol Obstet Invest 2005; 60: 195- 200.

23. Kumru S, Aydin S, Gursu MF, Ozcan Z. Changes of serum paraoxonase (an HDL-cholesterol-associated lipophilic antioxidant) and arylesterase activities in severe preeclamptic women. Eur J Obstet Gynecol Reprod Biol 2004; 114: 177- 81.

24. Baker AM, Klein RL, Haeri S, Moss KL, Boggess KA. Association of midgestational paraoxonase 1 activity with pregnancies complicated by preeclampsia. Am J Perinatol 2010; 27: 205- 10 